\title{
Correction: Systematic reviews in hematopoietic cell transplantation and cellular therapy: considerations and guidance from the American Society for Transplantation and Cellular Therapy, European Society for Blood and Marrow Transplantation, and the Center for International Blood and Marrow Transplant Research late effects and quality of life working committee
}

\author{
Akshay Sharma $(\mathbb{D} \cdot$ Sherif M. Badawy - Elizabeth M. Suelzer $(\mathbb{D} \cdot$ Hemant S. Murthy • Pinki Prasad - Hesham Eissa • \\ Paul A. Carpenter - Mehdi Hamadani (iD) Myriam Labopin (iD) Hélène Schoemans (iD) André Tichelli • \\ Rachel Phelan • Betty K. Hamilton (D) - David Buchbinder • Annie Im • Rebecca Hunter • Ruta Brazauskas • \\ Linda J. Burns iD
}

Published online: 3 May 2021

(c) The Author(s) 2021. This article is published with open access

Correction to: Bone Marrow Transplantation https://doi.org/10.1038/s41409-020-01199-1

Unfortunately, the Funding information was incorrect. The correct Funding is given below.

Funding: The National Heart, Lung, and Blood Institute (NHLBI) of the National Institutes of Health supported this publication under Award Number K23HL150232 (SMB). AS is the recipient of an American Society of Scholar Award. The CIBMTR is supported primarily by Public Health Service U24CA076518 from the National Cancer Institute (NCI), the NHLBI, and the National Institute of Allergy and Infectious Diseases (NIAID); R21HL140314 and U01HL128568 from the NHLBI; HHSH250201700006C, SC1MC31881-01-00, and HHSH250201700007C from the Health Resources and Services Administration (HRSA); and N00014-18-1-2850, N00014-18-1-2888, and N00014-20-1-2705 from the Office of Naval Research; Additional federal support is provided by P01CA111412, R01CA152108, R01CA215134,
R01CA218285, R01CA231141, R01AI128775, R01HL129472, R01HL130388, R01HL131731, U01AI069197, U01AI126612, and BARDA. The views expressed in this article do not reflect the official policy or position of the NIH, the Department of the Navy, the Department of Defense, HRSA, or any other agency of the United States Government.

The original article has been corrected.

Open Access This article is licensed under a Creative Commons Attribution 4.0 International License, which permits use, sharing, adaptation, distribution and reproduction in any medium or format, as long as you give appropriate credit to the original author(s) and the source, provide a link to the Creative Commons license, and indicate if changes were made. The images or other third party material in this article are included in the article's Creative Commons license, unless indicated otherwise in a credit line to the material. If material is not included in the article's Creative Commons license and your intended use is not permitted by statutory regulation or exceeds the permitted use, you will need to obtain permission directly from the copyright holder. To view a copy of this license, visit http://creativecommons. org/licenses/by/4.0/. 